\title{
ARE CEOS REWARDED FOR LUCK? THE ONES WITHOUT PRINCIPALS ARE*
}

\author{
Marianne Bertrand and Sendhil Mullainathan
}

The contracting view of CEO pay assumes that pay is used by shareholders to solve an agency problem. Simple models of the contracting view predict that pay should not be tied to luck, where luck is defined as observable shocks to performance beyond the CEO's control. Using several measures of luck, we find that CEO pay in fact responds as much to a lucky dollar as to a general dollar. A skimming model, where the CEO has captured the pay-setting process, is consistent with this fact. Because some complications to the contracting view could also generate pay for luck, we test for skimming directly by examining the effect of governance. Consistent with skimming, we find that better governed firms pay their CEO less for luck.

\section{INTRODUCTION}

CEO pay is usually viewed through the lens of principal agent models. Under this contracting view, pay is used to reduce the moral hazard problem that arises because CEOs often own very little of the firms they control. Shareholders (perhaps acting through the board or the compensation committee) optimally design the pay package in order to increase the CEO's incentive to maximize firm value. ${ }^{1}$ Simple models of the contracting view generate one important prediction. Shareholders will not reward CEOs for observable luck. By luck, we mean changes in firm performance that are beyond the CEO's control. Tying pay to

* The results in this paper were previously circulated as part of a larger working paper entitled "Do CEOs Set Their Own Pay? The Ones Without Principals Do." We are extremely grateful to Daron Acemoglu, Rajesh Aggarwal, George Baker, Patrick Bolton, Peter Diamond, Robert Gibbons, Denis Gromb, Brian Hall, Bengt Holmstrom, Caroline Hoxby, Glenn Hubbard, Lawrence Katz, Jörn-Steffen Pischke, Nancy Rose, David Scharfstein, Robert Shimer, Andrei Shleifer, Richard Thaler, and seminar participants at the University of California at Berkeley, Columbia University, the University of Chicago, Harvard University, the Massachusetts Institute of Technology, Princeton University, and the National Bureau of Economic Research Corporate Finance Summer Institute 1999 for very helpful comments. We thank Kenneth Ayotte and Michael Mitton for excellent research assistance, Michael Haid for giving us access to his data set of oil companies, and David Yermack for giving us access to his data on executive compensation. Financial support was provided by the Russell Sage Foundation, the Princeton Industrial Relations Section, and the Princeton Center for Economic Policy Studies. e-mail: mbertran@princeton.edu; mullain@mit.edu.

1. Murphy $[1985,1986]$ is a forerunner of the vast empirical literature on the contracting view. Murphy [1999] and Abowd and Kaplan [1999] summarize the CEO pay literature. Formal tests of the contracting view can be found in Gibbons and Murphy [1990, 1992], Garen [1994], Hubbard and Palia [1994], Bertrand and Mullainathan [1999], and Aggarwal and Samwick [1999a, 1999b].

(C) 2001 by the President and Fellows of Harvard College and the Massachusetts Institute of Technology.

The Quarterly Journal of Economics, August 2001 
luck, therefore, cannot provide better incentives and will only make the contract riskier [Holmstrom 1979]. ${ }^{2}$

This paper starts by examining whether or not CEOs are in fact paid for luck using three measures of luck. ${ }^{3}$ First, we perform a case study of the oil industry where large movements in oil prices tend to affect firm performance on a regular basis. Second, we use changes in industry-specific exchange rate for firms in the traded goods sector. Third, we use year-to-year differences in mean industry performance to proxy for the overall economic fortune of a sector. ${ }^{4}$ For all three measures, we find that CEO pay responds significantly to luck. In fact, we find that CEO pay is as sensitive to a lucky dollar as to a general dollar. Moreover, these results hold as well for discretionary components of pay-salary and bonus-as they do for options grants.

These results are inconsistent with a simple contracting view. Motivated by practitioners such as Crystal [1991], we propose an alternative, skimming, which can explain these results [Bertrand and Mullainathan 2000a]. The skimming view also begins with the separation of ownership and control, but it argues that this separation allows CEOs to gain effective control of the pay-setting process itself. Both because of entrenchment, such as packing the board with supporters, and because of the complexity of the pay process, many CEOs de facto set their own pay with little oversight from shareholders. Their pay level then becomes constrained by an unwillingness to draw shareholders' attention. Pay for performance arises in the skimming view because good performance may ease these constraints, in essence creating

2. Note our emphasis on observable luck. In any model, given the randomness of the world, CEOs (and almost everybody else) will end up being rewarded for unobservable luck. Note also our emphasis on the fact that this prediction holds in simple agency models. As we will discuss shortly, complications to the agency model can in principle alter this result.

3. Blanchard, Lopez-de-Silanes, and Shleifer [1994] present suggestive evidence on pay for luck by showing that windfall gains from court rulings raise the pay of CEOs. It is only suggestive since court rulings may not be luck but rather a result of the CEO's work. In other domains, Shea [1999] independently performs an exercise similar to ours for baseball players.

4. This last test very much resembles the approach followed in the relative performance evaluation (RPE) literature [Gibbons and Murphy 1990; Janakiraman, Lambert, and Larcker 1992; Aggarwal and Samwick 1999a]. Problems can arise with RPE as a special case of luck. Filtering this specific kind of luck may not be optimal from an agency theoretical point of view. As Gibbons and Murphy [1990] note, relative performance evaluation can distort CEO incentives if they can "take actions that affect the average output of the reference group." Aggarwal and Samwick [1999b] develop a formal model along these lines. By using other shocks to performance that are even more objectively beyond managerial influence, we circumvent these problems. 
slack for the CEO. In other words, when the firm is doing well, shareholders are less likely to notice a large pay package. To the extent that lucky dollars create slack as readily as general dollars, pay for luck arises.

Finding pay for luck, however, does not necessarily single out the skimming model. Complications to the agency model can make it such that paying for luck is in fact optimal. For example, suppose that the value of a CEO's human capital rises and falls with industry fortunes. One would then find that pay correlates with luck because the CEO's outside wage moves with luck. Another possibility is that boards may tie pay to luck in order to motivate CEOs to forecast or respond to luck shocks. Subsection II.D discusses whether arguments such as these can really explain the pay for luck relationship.

To further differentiate skimming from these explanations, we empirically examine a direct implication of the skimming model. Skimming should be less prevalent in better governed firms. Well-governed firms, such as those with a large shareholder present on the board, limit the CEO's ability to capture the pay process. We test this hypothesis using several measures of governance: presence of large shareholders (on the board and overall), CEO tenure (interacted with the presence of large shareholders to better proxy for entrenchment), board size, and fraction of directors that are insiders. Consistent with skimming, we generally find that the better governed firms pay less for luck. ${ }^{5}$ These effects are strongest for the presence of large shareholders on the board. An additional large shareholder on the board reduces pay for luck by between 23 and 33 percent. Large shareholders are especially important as CEO tenure increases, consistent with the idea that unchecked CEOs can entrench themselves over time. If pay for luck were optimal, we would have expected well-governed firms to pay for luck as much as (if not more than) poorly governed firms. For example, whether or not a large shareholder is present, the CEO would have to be rewarded for a rise in the value of his human capital. These findings suggest that at least some of the pay for luck in poorly governed firms is due to skimming by CEOs.

5. Whenever we refer to "less pay for luck" we mean that there is less pay for luck relative to the amount of pay for performance. Thus, these results would not be driven by well-governed firms simply giving less overall pay for performance. In fact, we find that governance correlates very little with pay for performance, only with pay for luck. 


\section{PAy FOR LuCK Test}

\section{II.A. Theoretical Background}

A simple theoretical model will make more precise what agency theory says about the reward for observable luck. Consider a standard agency setup where risk-neutral shareholders try to induce a risk-averse top manager to maximize firm performance. Since the actions of the CEO can be hard to observe, shareholders will be unable to sign a contract that specifies these actions. Instead, shareholders will offer a contract to the CEO where her compensation level is made to depend on the firm's performance. Let $p$ represent firm performance and $a$ the CEO's actions, which by assumption are unobservable to the shareholders. Firm performance depends on the actions of the CEO and on random factors. We split the random factors into two components: those that can be observed by shareholders and those that cannot. For an oil firm, the price of crude oil would be an observable random factor. Letting $o$ be the observable factor and $u$ be the unobservable noise term, we assume that performance can be written as $p=a+\delta o+u$.

Under some technical conditions (CARA utility and Brownian motion for the performance process), Holmstrom and Milgrom [1987] calculate the optimal incentive scheme for this model. Let $s$ denote this incentive scheme. Since shareholders can only observe two variables, $p$ and $o$, the incentive scheme could at most depend on these two variables. In fact, shareholders will only reward CEOs for performance net of the observable factor:

$$
s=\alpha+\beta(p-\delta o)=\alpha+\beta(a+u) .
$$

In other words, the optimal incentive scheme filters the observable luck from performance. This is because leaving $o$ in the incentive scheme provides no added benefit to the principal as, by definition, the agent has no control over $o$. Motivating her on $o$ has no incentive effects. Beyond providing no benefit, tying pay to luck actually costs the principal because the variance of the incentive scheme is higher, and the principal must increase mean pay to compensate the risk-averse CEO.

In practice, explicit incentive contracts, such as options, rarely filter. For example, options are rarely if ever indexed against market performance. This need not be inconsistent with a lack of filtering, however. It may be that the discretionary components of pay, such as salary and bonus, are the ones used to 
filter. In theory, these other components could adjust enough to undo the effect of the options value fluctuating with luck. Such adjustment may happen if a board were to monitor luck and alter each year's salary, bonus, and number of new options granted so that the CEO's overall pay package remains free of luck.

\section{II.B. Empirical Methodology}

Within the agency framework, most of the empirical literature on CEO pay estimates an equation of the form,

$$
y_{i t}=\beta * \operatorname{perf}_{i t}+\gamma_{i}+\chi_{t}+\alpha_{X} * X_{i t}+\epsilon_{i t},
$$

where $y_{i t}$ is total CEO compensation in firm $i$ at time $t$, perf $_{i t}$ is a performance measure, $\gamma_{i}$ are firm fixed effects, $\chi_{t}$ are time fixed effects, and $X_{i t}$ are firm- and CEO-specific variables such as firm size and tenure. The coefficient $\beta$ captures the strength of the pay for performance relationship.

Performance is typically measured either as changes in accounting returns or stock market returns, and we will use both measures. ${ }^{6}$ In measuring compensation $y_{i t}$, much of the literature focuses on the flow of new compensation. Ideally, the compensation in a given year would also include changes in the value of unexercised options granted in previous years [Hall and Liebman 1998]. Such a calculation requires data on the accumulated stock of options held by the CEO each year, whereas existing data sets, including ours, contain only information on new options granted each year. Consequently, our compensation measure excludes this component of the change in wealth. For our purposes, however, this exclusion does not pose much of a problem. The change in wealth due to changing option values is mechanically tied to luck since options are not indexed. Thus, even if these data were available, focusing on the subjective components of pay would still be a natural strategy. We discuss this issue at greater length in subsection II.D.

To estimate the general sensitivity of pay to performance, we will follow the literature and estimate equation (2) using a standard Ordinary Least Squares (OLS) model. To estimate the sensitivity of pay to luck, we need to use a two-stage procedure. In the first stage, we will predict performance using luck in order to isolate changes in performance that are caused by luck. In the

6. These are flow measures. In practice, given the firm fixed effects, we will use market value and level of accounting returns as measures of $p e r f_{i t}$. 
second stage, we will see how sensitive pay is to these predictable changes in performance. This two-stage procedure is essentially an Instrumental Variables (IV) estimation where the luck variable is the instrument for performance. ${ }^{7}$

Letting $o$ be luck, the first equation we estimate is

$$
\operatorname{perf}_{i t}=b * o_{i t}+g_{i}+c_{t}+a_{X} * X_{i t}+e_{i t},
$$

where $o_{i t}$ represents the luck measure (oil price, for example). From this equation we predict a firm's performance using only information about luck. Call this predicted value $\widehat{\operatorname{perf}}_{i t}$. We then ask how pay responds to these predictable changes in performance due to luck:

$$
y_{i t}=\beta_{\text {Luck }} * \widehat{\operatorname{per}} f_{i t}+\gamma_{i}+\chi_{t}+\alpha_{X} * X_{i t}+\epsilon_{i t} .
$$

The estimated coefficient $\beta_{L u c k}$ indicates how sensitive pay is to changes in performance that come from luck. Since such changes should be filtered, basic agency theory predicts that $\beta_{L u c k}$ should equal 0.

\section{II.C. Oil Industry Study}

We now turn to the oil industry as a case study of pay for luck. As Figures I and II show, the price of crude oil has fluctuated dramatically over the last 25 years. These large fluctuations have caused large movements in industry profits. Moreover, these large fluctuations in crude oil prices are likely to have been beyond the control of a single American CEO. For example, the sharp decline in crude oil price at the end of 1985 was caused by Saudi Arabia's decision to reform its petroleum policy and to increase production, an action hardly attributable (and never attributed) to the CEOs of American oil firms. Similarly, the large oil price increase between 1979 and 1981 is usually attributed to an internal policy change by OPEC. Oil price movements therefore provide an ideal place to test for pay for luck: they affect

7. One might wonder why we should use this procedure rather than simply include $o$ directly into the pay for performance equation (2) and run OLS to estimate

$$
y_{i t}=\beta * \operatorname{perf}_{i t}+\phi * o+\gamma_{i}+\chi_{t}+\alpha_{x} * X_{i t}+\epsilon_{i t} .
$$

This equation is hard to interpret, however. Even if there is no pay for luck, the coefficient $\phi$ will not equal $-\beta$ but rather $-\beta \delta$, as we can see from equation (1). Since we do not estimate $\delta$, the estimated coefficient $\phi$ can be small either because there is pay for luck or simply because $\delta$ is small. The first equation in the IV procedure circumvents this problem by scaling the effect of luck on performance. 


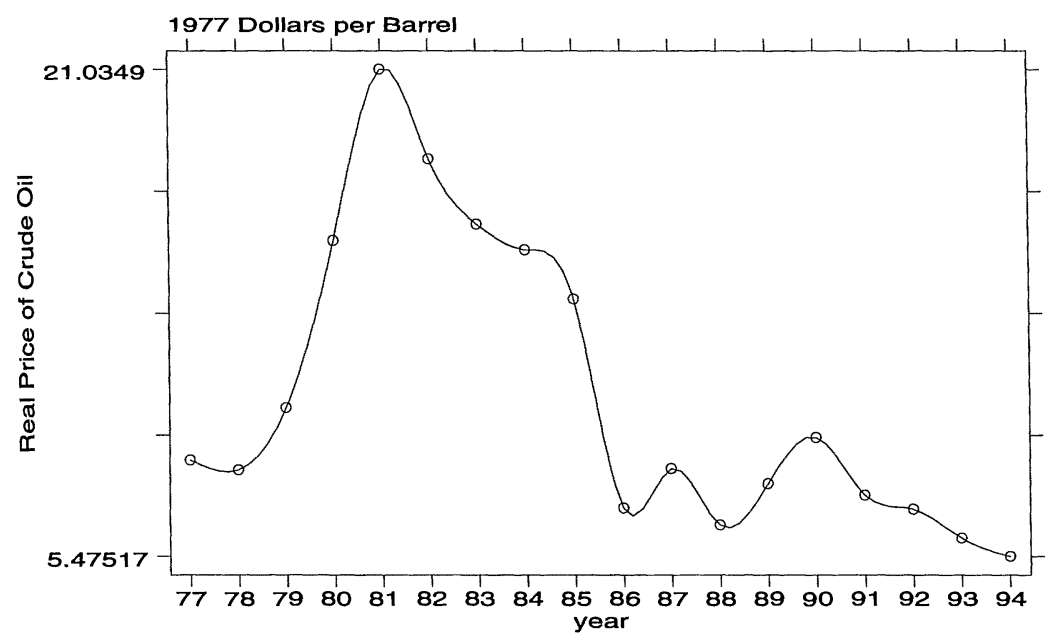

Figure I

Real Price of a Barrel of Crude Oil

performance, are measurable, and are plausibly beyond the control of the CEOs.

We use a data set on the pay and performance for the 51 largest American oil companies between 1977 and 1994 to imple-

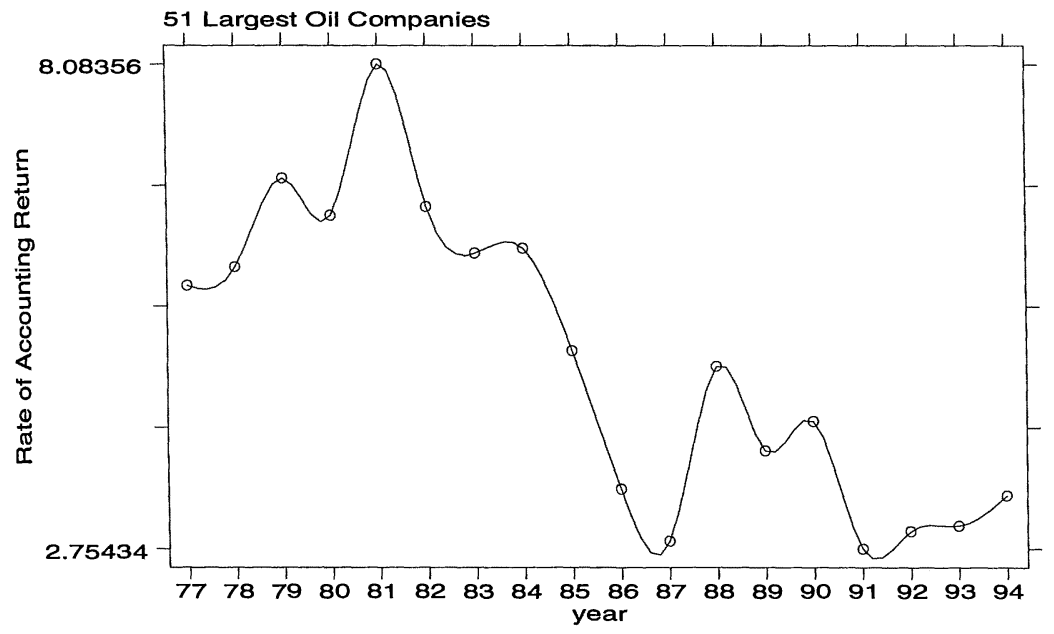

FiguRe II

Mean Rate of Accounting Return 


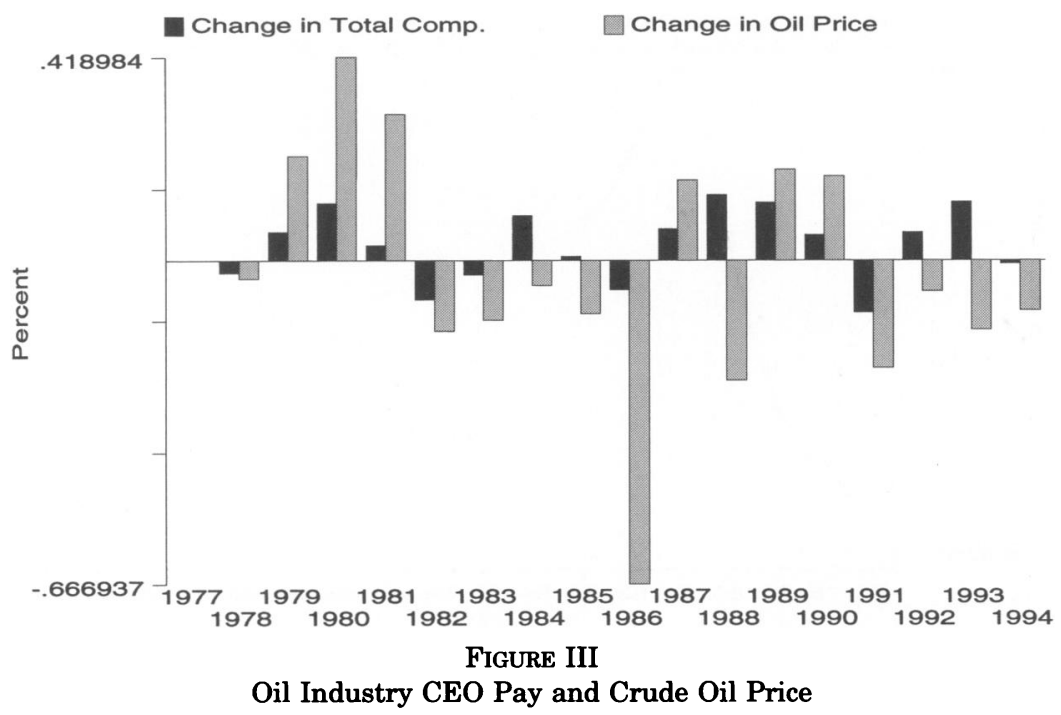

ment the methodology of the previous section. ${ }^{8}$ Before moving to regression analysis, it is useful to look directly at how pay fluctuates compared with the movements in Figures I and II. In Figure III we have graphed changes in oil prices for each year and changes in mean log pay in the industry. Two striking facts emerge. First, pay changes and oil price changes correlate quite well. In twelve of the seventeen years they are of the same sign: both are up, or both are down. This is suggestive of pay for luck. Second, the remaining five years where pay and oil prices move in opposite directions are all years in which the oil price drops. This hints at an asymmetry: while CEOs are always rewarded for good luck, they may not always be punished for bad luck.

This graphical analysis does not quantify pay for luck. One cannot compare it with the size of the overall pay for performance. It also does not control for other firm-specific variables that might be changing over time. Table I follows the empirical

8. We are extremely grateful to Michael Haid for making the data set used in this section available to us. See Haid [1997] for further details about the construction of the data set. Appendix 1 provides mean and standard deviations for the main variables of interest. While the original data set covers 51 companies over the period 1977 to 1994 , information on CEO pay is available for only 50 of these original 51 companies. Moreover, CEO pay is available from 1977 on for only 34 of these 50 companies. The final data set we use covers 827 company/year observations. 
TABLE I

Pay for Luck for OIl CEOs (Luck Measure is log Price of Crude Oil) DEPENDENT VARIABLE: In (TOTAL COMPENSATION)

\begin{tabular}{lcccc}
\hline \multicolumn{1}{c}{ Specification: } & $\begin{array}{c}\text { General } \\
(1)\end{array}$ & $\begin{array}{c}\text { Luck } \\
(2)\end{array}$ & $\begin{array}{c}\text { General } \\
(3)\end{array}$ & $\begin{array}{c}\text { Luck } \\
(4)\end{array}$ \\
\hline $\begin{array}{l}\text { Accounting rate } \\
\text { of return }\end{array}$ & .82 & 2.15 & - & - \\
Log (shareholder & $(.16)$ & $(1.04)$ & & \\
$\quad$ wealth) & - & - & .38 & .35 \\
Age & .05 & .07 & $(.03)$ & $(.17)$ \\
& $(.02)$ & $(.03)$ & .05 & .05 \\
Age ${ }^{2} * 100$ & -.04 & -.05 & -.04 & $(.02)$ \\
& $(.02)$ & $(.02)$ & $(.02)$ & -.04 \\
Tenure & .01 & .01 & .01 & $.02)$ \\
& $(.01)$ & $(.01)$ & $(.01)$ & $(.01)$ \\
Tenure ${ }^{2} * 100$ & -.03 & -.03 & -.03 & -.03 \\
& $(.02)$ & $(.01)$ & $(.02)$ & $(.02)$ \\
Firm fixed effects & Yes & Yes & Yes & Yes \\
Year quadratic & Yes & Yes & Yes & Yes \\
Sample size & 827 & 827 & 827 & 827 \\
Adjusted $R^{2}$ & .70 & - & .75 & - \\
\hline \hline
\end{tabular}

a. Dependent variable is the logarithm of total compensation. Performance measure is accounting rate of return in columns (1) and (2) and the logarithm of shareholder wealth in columns (3) and (4). All nominal variables are expressed in 1977 dollars.

b. Summary statistics for the sample of oil firms are available in Appendix 1.

c. The luck regression (columns (2) and (4)) instrument for performance with the logarithm of the price of a barrel of crude oil in that year, expressed in 1977 dollars.

d. Each regression includes firm fixed effects and a quadratic in year.

e. Standard errors are in parentheses.

methodology presented in subsection II.B, which permits a more systematic analysis. All regressions use log (total compensation) as dependent variable and include firm fixed effects, age and tenure quadratics, and a performance measure as dependent variables. ${ }^{9}$ We also include a year quadratic to allow for the fact that CEO pay has been trending up during this period. Column (1) estimates the sensitivity of pay to a general change in accounting performance. The coefficient of .82 suggests that if an oil firm increases its accounting return by one percentage point, total compensation rises by $.82 * .01=.0082 \log$ point. Roughly, a one percentage point increase in accounting returns leads to a .8 percent increase in pay. Note that the sign and magnitude of all the other covariates in the regression seem sensible. Pay in-

9. Total compensation in this table and all other tables includes salary, bonus, other incentive payments, and value of options granted in that year. 
creases with age and to a lesser extent with tenure. Both the age and tenure profile are concave (the negative coefficient on the quadratic term).

Column (2) estimates the sensitivity of pay to luck. As described above, we instrument for performance with the log of oil price. ${ }^{10}$ The coefficient in column (2) now rises to 2.15 . This suggests that a one percentage point rise in accounting returns due to luck raises pay by 2.15 percent. Given the large standard errors, one cannot reject that the pay for luck coefficient and pay for general performance coefficient are the same. One can, however, strictly reject the hypothesis of complete filtering: oil CEOs are paid for luck that comes from oil price movements.

Columns (3) and (4) perform the same exercise for a market measure of performance, shareholder wealth. The coefficient of .38 on column (3) suggests that a 1 percent increase in shareholder wealth leads to roughly a .38 percent increase in CEO pay. In column (4) we find that a 1 percent increase in shareholder wealth due to luck leads to .35 percent increase in CEO pay. Again, pay for luck matches pay for general performance.

\section{II.D. More General Tests}

The oil industry case study, while instructive, raises the question of how generalizable these results are. In this subsection we will examine luck shocks that affect a broader set of firms. We focus on two measures of luck: movements in exchange rates and mean industry performance. By affecting the extent of import penetration and hence foreign competition, exchange rate movements can strongly affect a firm's profitability. ${ }^{11}$ Movements in mean industry performance also proxy for luck to the extent that a CEO does not influence how the rest of her industry performs. As we mentioned before, this last instrument is more questionable. In practice, however, we find that mean industry movements operate exactly like exchange rate or oil price movements.

To implement these tests, we use compensation data on 792 large corporations over the 1984-1991 period. The data set was graciously made available to us by David Yermack and Andrei Shleifer. It is extensively described in Yermack [1995]. Compen-

10. This table does not report the first-stage regressions of performance on oil price. But as one would expect from Figures I and II, these regressions show very significant coefficients on oil price $(p<.001)$.

11. Revenga [1992] uses exchange rates as an instrument for import penetration. Bertrand [1999] shows its effects on firm profitability. 
sation data were collected from the corporations' SEC Proxy, $10-\mathrm{K}$, and 8- $\mathrm{K}$ fillings. Other data were transcribed from the Forbes magazine annual survey of CEO compensation as well as from SEC Registration statements, firms' Annual Reports, direct correspondence with firms, press reports of CEO hires and departures, and stock prices published by Standard \& Poor's. Firms were selected into the sample on the basis of their Forbes rankings. Forbes magazine publishes annual rankings of the top 500 firms on four dimensions: sales, profits, assets and market value. To qualify for the sample, a corporation must appear in one of these Forbes 500 rankings at least four times between 1984 and 1991. In addition, the corporation must have been publicly traded for four consecutive years between 1984 and 1991.

Yermack's data are attractive in that they provide both governance variables and information on options granted, not just information on options exercised. But they do not include changes in the value of options held, which we must therefore exclude from our compensation measure. If anything, this biases us toward understanding the amount of pay for luck. Since options are not indexed, changes in the value of options held will covary perfectly with luck. Including these changes in the compensation measure would only increase the measured pay for luck. This data limitation, therefore, is less of a concern for our purposes.

Table II presents summary statistics for the main variables of interest in the full Yermack data. ${ }^{12}$ All nominal variables are expressed in 1991 dollars. The average CEO earns $\$ 900,000$ in salary and bonus. His total compensation is nearly twice that amount at $\$ 1,600,000$. The difference indicates the large fraction of a CEO's pay that is due to options grants. The average CEO is roughly 57 years old and has been CEO of the firm for nine years. As far as governance goes, the average firm in our sample has 1.12 large shareholders, of which less than a fourth are sitting on the board. There are on average thirteen directors on a board. Forty-two percent of them are insiders. ${ }^{13}$

12. In practice, depending on the required regressors, the various tests in the following sections will be performed on various subsamples of the original data. None of these main variables of interest significantly differ in any of these subsamples.

13. Technically, we define insiders to be both inside and gray directors. An inside director is defined as a director who is a current or former officer of the company. A gray director is a relative of a corporate officer, or someone who has substantial business relationships with the company outside the course of regular business. 
TABLE II

Summary Statistics: Full Yermack CEO SAmple

\begin{tabular}{lcc}
\hline \hline & Mean & S. D. \\
\hline Age of CEO & 57.42 & 6.84 \\
Tenure of CEO & 9.10 & 8.08 \\
Salary and bonus & 901.69 & 795.15 \\
ln (Salary and bonus) & 6.62 & .60 \\
Total compensation & 1595.85 & 3488.32 \\
ln (Total compensation) & 6.98 & .81 \\
Number of large shareholders (All) & 1.12 & 1.42 \\
Number of large shareholders on board & .24 & .74 \\
Board size & 13.45 & 4.54 \\
Fraction of insiders on board & .42 & .19 \\
\hline \hline
\end{tabular}

a. Sample period is 1984-1991.

b. All nominal variables are expressed in thousands of 1991 dollars.

c. Column 1 is the mean for each variable, while column 2 is the standard deviation.

d. A large shareholder is defined as someone who owns more than 5 percent of the common shares in the company, excluding the CEO. Insiders here denote directors who are current or former officers of the company, relatives of corporate officers, or anyone who has a substantial business relationship with the company. Relationships arising in the normal course of business would not be called an insider. Our insider definition corresponds to insider + gray in the original Yermack data.

e. Total compensation equals salary plus bonus plus total value of options grants plus other compensation.

Our first general measure of luck focuses on exchange rate movements. We exploit the fact that exchange rates between the U. S. dollar and other country currencies fluctuate greatly over time. We also exploit the fact that different industries are affected by different countries' exchange rates. For example, since the toy industry may be more affected by Japanese imports while the lumber industry may be more affected by Bolivia, these two industries may experience very different shocks in the same year. This allows us to construct industry-specific exchange rate movements which are arguably beyond a specific CEO's control since they are primarily determined by macroeconomic variables. The exchange rate shock measure is based on the weighted average of the log real exchange rates for importing countries by industry. The weights are the share of each foreign country's import in total industry imports in a base year (1981-1982). Real exchange rates are nominal exchange rates (expressed in foreign currency per dollar) multiplied by U. S. CPI and divided by the foreign country CPI. Nominal exchange rates and foreign CPIs are from the International Financial Statistics of the International Monetary Fund. 
TABLE III

PAY FOR LUCK

\begin{tabular}{|c|c|c|c|c|c|c|c|c|c|c|}
\hline \multirow{2}{*}{$\begin{array}{c}\text { Dep. var.: } \\
\text { Specification: }\end{array}$} & \multicolumn{2}{|c|}{ Cash comp } & \multicolumn{2}{|c|}{$\ln ($ cash) } & \multicolumn{2}{|c|}{$\begin{array}{l}\ln (\text { total } \\
\text { comp) }\end{array}$} & \multicolumn{2}{|c|}{$\ln (\operatorname{cash})$} & \multicolumn{2}{|c|}{$\begin{array}{l}\text { ln (total } \\
\text { comp) }\end{array}$} \\
\hline & General & Luck & General & Luck & General & Luck & General & Luck & General & Luck \\
\hline \multicolumn{11}{|c|}{ Panel A: Luck Measure is Exchange Rate Shock } \\
\hline Income & $\begin{array}{c}.17 \\
(.02)\end{array}$ & $\begin{array}{c}.35 \\
(.16)\end{array}$ & - & - & - & - & - & - & - & - \\
\hline Income/assets & - & - & $\begin{array}{c}2.13 \\
(.16)\end{array}$ & $\begin{array}{c}2.94 \\
(1.28)\end{array}$ & $\begin{array}{l}2.36 \\
(.28)\end{array}$ & $\begin{array}{c}4.39 \\
(2.17)\end{array}$ & - & - & - & - \\
\hline $\begin{array}{l}\text { In (shareholder } \\
\text { wealth) }\end{array}$ & - & - & - & - & - & - & $\begin{array}{l}.22 \\
(.02)\end{array}$ & $\begin{array}{c}.32 \\
(.13)\end{array}$ & $\begin{array}{c}.31 \\
(.03)\end{array}$ & $\begin{array}{c}.57 \\
(.23)\end{array}$ \\
\hline Sample size & 1737 & 1737 & 1729 & 1729 & 1722 & 1722 & 1713 & 1713 & 1706 & 1706 \\
\hline Adjusted $R^{2}$ & .75 & - & .75 & - & .58 & - & .75 & - & .59 & - \\
\hline \multicolumn{11}{|c|}{ Panel B: Luck Measure is Mean Industry Performance } \\
\hline Income & $\begin{array}{l}.21 \\
(.02)\end{array}$ & $\begin{array}{l}.34 \\
(.10)\end{array}$ & - & - & - & - & - & - & - & - \\
\hline Income/assets & - & - & $\begin{array}{l}2.18 \\
(.12)\end{array}$ & $\begin{array}{l}4.02 \\
(.53)\end{array}$ & $\begin{array}{c}2.07 \\
(.21)\end{array}$ & $\begin{array}{l}4.00 \\
(.86)\end{array}$ & - & - & - & - \\
\hline $\begin{array}{l}\text { In (shareholder } \\
\text { wealth) }\end{array}$ & - & - & - & - & - & - & $\begin{array}{l}.20 \\
(.01)\end{array}$ & $\begin{array}{c}.22 \\
(.12)\end{array}$ & $\begin{array}{l}.25 \\
(.02)\end{array}$ & $\begin{array}{l}.29 \\
(.19)\end{array}$ \\
\hline Sample size & 4684 & 4684 & 4648 & 4648 & 4624 & 4624 & 4608 & 4608 & 4584 & 4584 \\
\hline Adjusted $R^{2}$ & .77 & - & .81 & - & .70 & - & .82 & - & .71 & - \\
\hline
\end{tabular}

a. Dependent variable is the level of salary and bonus in columns 1 and 2 , the logarithm of salary and bonus in columns 3, 4, 7, and 8 and the logarithm of total compensation in columns 5, 6, 9, and 10 . Performance measure is operating income before extraordinary items in columns 1 and 2 (in millions), operating income to total assets in columns 3 to 6 and the logarithm of shareholder wealth in columns 7 to 10. All nominal variables are expressed in real dollars.

b. In the luck regressions in Panel A, the performance measure is instrumented with current and lagged appreciation and depreciation dummies and current and lagged exchange rate index growth. First-stage regressions are presented in Appendix 2.

c. In the luck regressions in Panel B, the performance measure is instrumented with the total assetsweighted average performance measure in the firm's two-digit industry (the firm itself is excluded from the mean calculation).

d. Each regression includes firm fixed effects, year fixed effect and demographic controls (quadratics in age and tenure).

e. Standard errors are in parentheses.

Panel A of Table III examines this luck measure. Note that since the exchange rate measure can only be constructed for industries where we have imports data, the sample size is much smaller here than for our full sample. All regressions control for firm and year fixed effects as well as for quadratics in tenure and age. ${ }^{14}$ Column 1 uses as dependent variable the level of cash

14. We do not report the coefficients on age and tenure to save space, but they resemble the oil industry findings: positive but diminishing effects of tenure and age. 
compensation. Thus, relative to our standard specification, we do not run this regression in logs and do not include value of options granted. Since profits are reported in millions and pay is reported in thousands, the coefficient of .17 in column 1 suggests that $\$ 1000$ increase in profits leads to a 17 cent increase in performance. Column 2 performs the same exercise for pay for luck: we instrument for performance using the exchange rate shocks. ${ }^{15} \mathrm{As}$ in the oil case, we find a pay for luck coefficient that is of the same order of magnitude as the pay for general performance coefficient.

Columns 3 through 6 run the more standard regression where we use the logarithm of pay and an accounting measure of performance (operating income divided by total assets). In columns 3 and 4 we use only cash compensation, while in columns 5 and 6 we use total compensation. In both cases, we find the sensitivity of pay to luck to be about the same as the sensitivity of pay to general performance. When accounting performance rises by one percentage point, compensation (either total or cash) rises by about 2 percent, whether that rise was due to luck-exchange rate movements-or not.

Columns 7 through 9 replicate these four columns for market measures of performance. Again, we find pay for luck that matches the pay sensitivity to a general shock. A 1 percent increase in shareholder wealth raises pay (again either total or cash) of about .3 percent, irrespective of whether this rise was caused by luck or not.

Two important points should be taken away from this panel. First, the average firm rewards its CEO as much for luck as it does for a general movement in performance. There seems to be very little if any filtering at all. Since we use a totally different shock, these findings address theoretical concerns about the use of mean industry shocks (such as those raised in Gibbons and Murphy [1990] and Aggarwal and Samwick [1999b]) and show that the lack of filtering observed in RPE findings generalizes to other sources of luck.

Second, there is as much pay for luck on discretionary components of pay (salary and bonus) as there is on other components

15. First-stage regressions are reported in Appendix 2. In practice, we use as instruments continuous variables for exchange rate appreciation (current and lagged) as well as dummies to allow for nonlinear effects of appreciation (also current and lagged). The dummies are formed at the 2 and 4 percent cutoffs both for appreciation and depreciation. The instruments are jointly highly significant, with first-stage $p$-values of less than 1 percent in all cases. 
such as options granted. This rules out the notion that pay for luck mechanically arises because firms commit (implicitly or explicitly) to multiyear stock option plans where the number of options grants is fixed ahead of time. Under such plans, as firm value rises, so does the value of precommitted options grants [Hall 1999]. Because salary and bonus are the most subjective components of pay, finding pay for luck on these variables is very suggestive. Boards are rewarding CEOs for luck even when they could filter it.

In Panel B of Table III, we replicate Panel A except that our measure of luck becomes mean performance of the industry, which is meant to capture external shocks that are experienced by all the firms in the industry. More specifically, as an instrument for firm-level rate of accounting return in a given year, we use the weighted average rate of accounting return in that year in the two-digit industry that firm belongs to, excluding the firm itself from the calculation. ${ }^{16}$ The weight of a given firm in a given year is the share of its total assets in the aggregate "total assets" of the two-digit industry the firm belongs to. Similarly, as an instrument for firm-level logarithm of shareholder wealth in a given year, we use the weighted average of the log values of shareholder wealth in the two-digit industry in that year, again excluding the firm itself from the calculation and using total assets to weight each individual firm. ${ }^{17}$

As in Panel A, all regressions include firm fixed effects and year fixed effects. We also control for a quadratic in CEO age and a quadratic in CEO tenure. The regressions include more than twice the data points of Panel A because we can now use all firms, not only those in the traded goods sector. Panel B shows a pattern quite similar to Panel A. The pay for luck relationship in all specifications again roughly matches the pay for general performance. Besides reinforcing the findings of Panel A, these latest findings suggest that previous RPE results arose probably not because of mismeasurement of the reference industry or of the industry shock but because of true pay for luck.

16. We also investigated the use of one-digit and three-digit industry means as instruments and found qualitatively similar results.

17. These mean industry performance measures are constructed from COMPUSTAT. To maximize consistency of the performance measures between Yermack's firms and the rest of industry, we also compute shareholder wealth and income to assets ratios from COMPUSTAT for the firms in Yermack's. Because not all firms in Yermack's data are present in COMPUSTAT in every year, we lose about 800 firm-year observations. 


\section{Why Is There PAy for Luck?}

The results so far clearly establish pay for luck. There are several reactions possible to this evidence. First, one could take it as evidence of skimming. To understand how the skimming model predicts pay for luck, consider a CEO who has captured the pay process. His primary worry in setting pay will be that outrageous skimming may cause otherwise passive investors to stand up and notice. Good performance, however, provides the CEO with extra slack. For example, shareholders may scrutinize a firm more closely during bad times. This allows higher pay when performance is good and produces a positive link between pay and performance, but for different reasons than in the contracting view. If good performance creates slack irrespective of whether it was lucky, pay for luck will result. ${ }^{18}$

Alternatively, one could argue that pay for luck is in fact optimal and that the evidence so far is consistent with the contracting view. One reason why pay for luck might be optimal is that the CEO's outside option may in fact depend on luck. When the oil industry enjoys a good fortune, the human capital of oil CEOs may simply become more valuable. Firms then pay their oil CEOs more simply to match their increased outside options. Thus, pay for luck is optimal here not as an incentive device, but merely because the optimal level of pay increases with luck. ${ }^{19}$

Objections can be raised against this view. First, our suggestive evidence of asymmetry in pay for luck may be hard to reconcile with this view. Average CEO compensation in the oil industry always goes up when the price of crude oil goes up but does not always go down when the price of crude oil goes down. In our full sample, we performed a similar test using the industry luck shock. For accounting measures, we again found that pay responds more to positive industry shocks than to negative ones (with no asymmetry on general pay for performance). For market

18. The scrutiny of otherwise passive investors may be triggered by absolute performance for several reasons. The very nature of deciding where to pay attention requires focusing on variables immediately at hand. Passive investors may use accounting returns, earnings growth, or stock return in deciding when to act on a firm and all these variables are clearly not prefiltered. The idea that outrageous pay actually produces political intervention of some form has been pointed out in Jensen and Murphy [1990]. Empirical work on this can be found in Joskow, Rose, and Wolfram [1996].

19. While the argument made here is rather imprecise, Himmelberg and Hubbard [2000] provide a formal model as well as empirical results that interpret pay for luck in this light. 
measures, we could not reject symmetry. Second, it is unclear why a CEO's human capital should become more valuable as industry fortunes rise. In fact, it may be exactly in bad times that having the right CEO is most valuable. A priori, either relationship seems plausible. To test this assumption, we examined turnover in the CEO market. We found no statistically significant relationship between a CEO's turnover and industry returns (after controlling for the firm's returns) and a point estimate that was negative. This suggests that, if anything, turnover is countercyclical. Third, we tested the effect of the industry's average CEO turnover rate on pay for luck. If pay for luck were caused by market competition for CEOs, then industries with higher turnover should exhibit the greatest pay for luck. For accounting measures, we found that industries with the highest turnover in fact showed the least pay for luck. For market measures of performance, we found no relationship between industry turnover and pay for luck. Of course, for the last two findings, one could always argue that competitive pressures operate through the threat of turnover rather than through actual turnover. As a whole, though, we have been unable to find positive evidence that outside bidding up of CEO wages could explain our results.

Another reason why pay for luck may be optimal is that one may want to provide incentives to the CEO to forecast or respond to luck. ${ }^{20}$ This kind of argument can be most readily evaluated in our oil industry application. Suppose that a particularly talented CEO in the oil industry understood the political subtleties of the Arab countries and forecast the coming of the positive oil shock at the beginning of the $1980 \mathrm{~s}$. By increasing output from existing oil wells, increasing inventories, or intensifying search for new wells, he could have increased his firm's profits when the shock did come. Shouldn't shareholders reward this farsighted CEO? The important point here is that those CEOs who were exceptional in having forecast should indeed be rewarded. But this is not what we test for. We use none of the between firm variation in response to the oil shock. We merely test whether the average firm experiences a rise (or fall, for the negative shocks) in pay. Put another

20. An argument similar to hedging has been made by Diamond [1998]. Tying pay to luck may generate incentives for the CEO to change his correlation with the luck variable. In practice, diversification seems to be more in the interest of management than shareholders. Tufano [1996], for example, demonstrates that managerial characteristics, such as share or option ownership, are quite predictive of risk management in a sample of gold firms. 
way, our results suggest that a CEO who responds to the shock exactly the same way as every other oil CEO is rewarded. This cannot be a reward for having forecast well. Again, one may want to reward CEOs for exceptional responsiveness to shocks, but there is little reason to reward them for just average responsiveness.

A final set of responses to pay for luck would be to abandon the literal contracting view and argue that filtering out luck is simply impossible. This might be because of cognitive complexity in understanding what is luck and what is not luck. Part of this cognitive complexity may be a pure information issue if there are not enough data available to figure out the appropriate effect of luck. For example, estimating the coefficient $\delta$ in equation (1) may simply not be possible. Part of the cognitive complexity may be psychological as in the evidence on the fundamental attribution error [Durell 1999]. ${ }^{21}$ None of the evidence so far directly refutes this argument.

\section{III.A. The Effect of Governance}

While we have argued against some of the various extensions of the simple agency model, in the end we still believe that they merit serious consideration. They suggest to us that the pay for luck finding does not per se rule out agency models. The results are also consistent with the idea that filtering out luck is just not feasible. Therefore, we now turn to testing a specific prediction of the skimming view rather than arguing against the other views. Since the skimming view emphasizes the CEO's ability to gain control of the pay process, corporate governance should play an important role in skimming. It is exactly in the poorly governed firms where we expect CEOs to most easily gain control of the pay process. This suggests that we should expect more pay for luck in the poorly governed firms. ${ }^{22}$

21. Another possibility is that luck is not contractible. In practice, we do not believe this is important for most of our findings. First, it is difficult to believe that noncontracting issues can explain our results in the oil industry case study: the price of crude oil can easily be measured and written into a contract. Second, even in the presence of noncontractibility, subjective performance evaluation should effectively filter (see Baker, Gibbons, and Murphy [1994]).

22 . Would the alternative explanations above predict an effect of governance? First, one might argue that better governance increases the efficacy of monitoring mechanisms and hence reduces the need to pay for performance. This argument would predict a change in the overall level of pay for performance, not only in pay for luck. We circumvent this problem by looking at the change in pay for luck relative to the change in general pay for performance. As an aside, general pay for 
To examine how pay for luck differs between well-governed and poorly governed firms, we estimate two equations. First, in order to provide a baseline, we ask how pay for general performance (not luck) differs between well-governed and poorly governed firms. We estimate an OLS equation similar to equation (2) except that we allow the pay for performance coefficient to depend on governance:

$$
\begin{aligned}
y_{i t}=\beta * \operatorname{perf}_{i t}+\theta * & \left(\operatorname{Gov}_{i t} * \operatorname{perf}_{i t}\right) \\
& +\gamma_{i}+\chi_{t}+\alpha_{X} * X_{i t}+\alpha_{G} * \operatorname{Gov}_{i t}+\epsilon_{i t},
\end{aligned}
$$

where $G_{o v}$ it is a measure of governance. To understand this equation, differentiate both sides with respect to performance to get $\partial y_{i t} / \partial p e r f_{i t}=\beta+\theta * G o v_{i t}$. In words, this specification allows the pay for performance sensitivity to be a function of the governance variable. A positive value for $\theta$ would imply that better governed firms show greater pay for performance.

Equation (3) of course tells us nothing about pay for luck, merely about pay for performance. To get at pay for luck, we reestimate this equation using our two-stage instrumental variables procedure. ${ }^{23}$ We then compute an estimate of the effect of governance on pay for general performance, $\hat{\theta}$ and an estimate of the effect of governance on pay for luck, $\hat{\theta}_{L u c k}$.

Our test then consists in comparing $\hat{\theta}$ and $\hat{\theta}_{L u c k}$. We will speak of more pay for luck in poorly governed firms when poorly governed firms display more pay for luck relative to pay for general performance. If poorly governed firms simply gave more pay for performance and pay for luck rose as a consequence, we would not refer to this as more pay for luck. In practice, we will see that it is pay for luck that changes with governance, while pay for performance hardly changes. We will also verify that these

performance does not systematically correlate with governance. Second, for theories that rely on changes in the value of the CEO's human capital, it is unclear why these changes would happen more in the poorly governed firms. Finally, the presumption that filtering is somehow cognitively impossible would clearly be refuted if some firms could filter.

23. An extremely important caveat here: our approach allows for the possibility that better governed firms may have a different responsiveness of performance to luck. So, for example, if well-governed firms were merely less responsive in their performance (not their pay) to luck, this would not create a spurious pay for luck difference between well-governed and poorly governed firms. Technically, performance perf ${ }_{i t}$, the endogenous variable we need to instrument, appears both directly and indirectly (the term Gov $_{i t} * \operatorname{perf}_{i t}$ ) in this equation. When we instrument, we perform two first stages, one for the direct effect perf $f_{i t}$ and one for the interaction term $\operatorname{Gov}_{i t} * \operatorname{perf}_{i t}$. This procedure is crucial because it allows the effect of luck on performance to depend on governance. 
TABLE IV

LaRge Shareholders and Pay For Luck (Luck Measure Is Mean Industry Performance) DePendent VARIABLE: ln (Total Compensation)

\begin{tabular}{|c|c|c|c|c|c|c|c|c|}
\hline \multirow{2}{*}{$\begin{array}{c}\text { Governance measure: } \\
\text { Specification: }\end{array}$} & \multicolumn{4}{|c|}{ Large shareholders } & \multicolumn{4}{|c|}{ Large shareholders on board } \\
\hline & $\begin{array}{l}\text { General } \\
\text { (1) }\end{array}$ & $\begin{array}{l}\text { Luck } \\
(2)\end{array}$ & $\begin{array}{c}\text { General } \\
\text { (3) }\end{array}$ & $\begin{array}{l}\text { Luck } \\
\text { (4) }\end{array}$ & $\begin{array}{c}\text { General } \\
\text { (5) }\end{array}$ & $\begin{array}{l}\text { Luck } \\
(6)\end{array}$ & $\begin{array}{l}\text { General } \\
\text { (7) }\end{array}$ & $\begin{array}{c}\text { Luck } \\
(8)\end{array}$ \\
\hline Income Assets & $\begin{array}{l}2.18 \\
(.238)\end{array}$ & $\begin{array}{l}4.59 \\
(.912)\end{array}$ & - & - & $\begin{array}{l}2.14 \\
(.217)\end{array}$ & $\begin{array}{l}4.49 \\
(.882)\end{array}$ & - & - \\
\hline $\begin{array}{l}\text { Governance* } \\
\text { Income/assets }\end{array}$ & $\begin{array}{c}-.094 \\
(.094)\end{array}$ & $\begin{array}{c}-.416 \\
(.204)\end{array}$ & - & - & $\begin{array}{c}-.181 \\
(.176)\end{array}$ & $\begin{array}{r}-1.48 \\
(.396)\end{array}$ & - & - \\
\hline $\begin{array}{l}\text { In (shareholder } \\
\text { wealth) }\end{array}$ & - & - & $\begin{array}{l}.249 \\
(.018)\end{array}$ & $\begin{array}{l}.383 \\
(.219)\end{array}$ & - & - & $\begin{array}{l}.258 \\
(.017)\end{array}$ & $\begin{array}{l}.318 \\
(.199)\end{array}$ \\
\hline $\begin{array}{l}\text { Governance* } \\
\text { Log (shareholder } \\
\text { wealth) }\end{array}$ & - & - & $\begin{array}{c}.001 \\
(.007)\end{array}$ & $\begin{array}{l}-.066 \\
(.036)\end{array}$ & - & - & $\begin{array}{c}-.019 \\
(.016)\end{array}$ & $\begin{array}{r}-.076 \\
(.053)\end{array}$ \\
\hline Governance & $\begin{array}{c}-.009 \\
(.011)\end{array}$ & $\begin{array}{l}.018 \\
(.018)\end{array}$ & $\begin{array}{c}-.017 \\
(.049)\end{array}$ & $\begin{array}{l}.411 \\
(.240)\end{array}$ & $\begin{array}{c}-.006 \\
(.021)\end{array}$ & $\begin{array}{c}.084 \\
(.033)\end{array}$ & $\begin{array}{l}.100 \\
(.108)\end{array}$ & $\begin{array}{l}.480 \\
(.356)\end{array}$ \\
\hline Sample size & 4610 & 4610 & 4570 & 4570 & 4621 & 4621 & 4581 & 4581 \\
\hline Adjusted $R^{2}$ & .695 & & .706 & & .694 & & .706 & \\
\hline
\end{tabular}

a. Dependent variable is the logarithm of total compensation. performance measure is operating income to total assets. All nominal variables are expressed in real dollars.

b. In all the luck regressions, both the performance measure and the interaction of the performance measure with the governance measure are instrumented. The instruments are the asset-weighted average performance in the two-digit industry and the interactions of the industry performance with that governance measure.

c. "Large shareholders" indicates the number of blocks of at least 5 percent of the firm's common shares, whether the block holder is or is not a director. "Large shareholders on board" indicates the number of blocks of at least 5 percent of the firm's common shares that are held by directors of the board.

d. Each regression includes firm fixed effects, year fixed effects, a quadratic in age, and a quadratic in tenure.

e. Standard errors are in parentheses.

results are robust to allowing pay for luck to vary by firm size. Otherwise, one might simply worry that governance is a proxy for size. $^{24}$

In Table IV, we implement this framework for the case of large shareholders. We ask whether the presence of large shareholders affects pay for luck. Shleifer and Vishny [1986], among others, argue that large shareholders improve governance in a firm. A single investor who holds a large block of shares in a firm

24. One must also be careful in interpreting the results from this exercise. They are merely suggestive of the cross-sectional relationship between governance and the extent of skimming. They do not necessarily imply that a policy of changing a specific governance variable will necessarily lead to a change in the extent of skimming. To make strong policy suggestions such as this, one would need more exogenous variation in governance and see its effects on CEO pay, such as in Bertrand and Mullainathan [1999]. The governance results here are useful because they demonstrate the relevance of the skimming view and not because they isolate policy mechanisms to reduce skimming. 
will have greater incentives to watch over the firm than a dispersed group of small shareholders. ${ }^{25}$ In our context, the idea of large shareholders fits most naturally as this matches the intuition of "having a principal around." Yermack data contain a variable that counts the number of individuals who own blocks of at least 5 percent of the firm's common shares. When the CEO happens to own such a block, we exclude this block from the count. We further know whether these large shareholders are on the board or not. A priori, one might expect that large shareholders on the board have the greatest impact. They can exert their control not just through implicit pressure or voting, but also with a direct voice on the board. Since the information is available, we will consider the effect both of all large shareholders and of only those on the board.

The first four columns of Table IV use all large shareholders as our measure of governance. All regressions include the usual controls. Column (1) estimates how the sensitivity of pay to performance depends on governance for accounting measures of performance. The first row tells us that a firm with no large shareholders shows a sensitivity of log compensation to accounting return of 2.18. An increase in accounting return of one percentage point leads to an increase in pay of about 2 percent. The second row tells us that adding a large shareholder only weakly decreases the sensitivity of pay to general performance, and this effect is not statistically significant. For example, a one percentage point increase in accounting return now leads to a 2.09 percent increase in pay when the firm has one large shareholder (compared with 2.18 in the absence of any large shareholder). Column (2) estimates how large shareholders affect pay for luck. ${ }^{26}$ As before, the first row tells us that there is significant pay for luck. The second row here, however, tells us that this pay for luck diminishes significantly in the presence of a large shareholder. A one percentage point increase in accounting returns due to luck leads to roughly a 4.6 percent increase in pay when there is no large shareholder but only a 4.2 percent increase in pay

25. They also point out a possible opposing effect: very large shareholders may have a greater ability to expropriate rents for themselves. This effect is likely to be greatest in other countries where investor protection is weakest. Empirical evidence on the efficacy of large shareholders can be found in Zeckhauser and Pound [1990], Shivdasani [1993], and Denis and Serrano [1996].

26. In all that follows, we will use mean industry performance as our measure of luck since this produces the most powerful first stages in the IV framework. 
when there is one more large shareholder. Each additional large shareholder decreases this effect by .4 percent. This is a 10 percent drop in the pay for luck coefficient for each additional large shareholder. ${ }^{27}$

Columns (3) and (4) estimate the same regressions using market measures of performance. In this case, the pay for general performance does not depend at all on the existence of a large shareholder (a coefficient of .001 with a standard error of .007). We again find, however, that pay for luck diminishes with the presence of a large shareholder. While the result is only significant at the 10 percent level, the economic magnitude is larger. The pay for luck coefficient now drops $.066 / .383 \approx 17$ percent for each large shareholder.

In columns (5) through (8) we repeat the above exercise but alter the governance measure. We now focus only on large shareholders on the board. Comparing columns (6) and (2), we see that the governance effect strengthens significantly with respect to the filtering of accounting performance. We see that the pay for luck drops by 33 percent for each additional large shareholder. The results are very statistically significant. On market performance measures, we find the effect also rises but less dramatically. In column (8) the pay for luck drops 23 percent with each large shareholder on the board. Moreover, this last result is insignificant. In summary, our findings in Table IV highlight how large shareholders (especially those on the board) affect the extent of pay for luck. Firms with more large shareholders show for less pay for luck.

The results in Table IV simply compare firms with large shareholders with firms without. This ignores the effects of CEO tenure, another important determinant of governance. A common belief is that CEOs who have been with the firm longer have had a chance to become entrenched, perhaps by appointing friends on the board. In this case, we would expect high tenure CEOs to

27. One may recall from subsection II.D that we are excluding the cumulated options from our measure of compensation as these will mechanically covary with stock price and, hence luck. However, if firms with large shareholders provided more options, they may effectively provide more pay for luck because a bigger fraction of compensation (and hence for pay for luck) comes from the mechanical portion. To test at least this presumption, we compared the fraction of total compensation that were options grants between well-governed and poorly governed firms. We found no consistent economically or statistically significant difference for our governance measures. 
TABLE V

Tenure, Large Shareholders, and Pay for Luck (Luck Measure Is Mean Industry Performance) Dependent VARIABLE: $\ln$ (Total Compensation)

\begin{tabular}{|c|c|c|c|c|c|c|c|c|}
\hline \multirow[b]{3}{*}{ Specification: } & \multicolumn{8}{|c|}{ Any large shareholder on the board? } \\
\hline & \multicolumn{2}{|c|}{ No } & \multicolumn{2}{|c|}{ Yes } & \multicolumn{2}{|c|}{ No } & \multicolumn{2}{|c|}{ Yes } \\
\hline & $\begin{array}{l}\text { General } \\
\text { (1) }\end{array}$ & $\begin{array}{l}\text { Luck } \\
(2)\end{array}$ & $\begin{array}{l}\text { General } \\
\text { (3) }\end{array}$ & $\begin{array}{c}\text { Luck } \\
(4)\end{array}$ & $\begin{array}{l}\text { General } \\
\text { (5) }\end{array}$ & $\begin{array}{l}\text { Luck } \\
(6)\end{array}$ & $\begin{array}{l}\text { General } \\
\text { (7) }\end{array}$ & $\begin{array}{c}\text { Luck } \\
(8)\end{array}$ \\
\hline Income Assets & $\begin{array}{l}2.14 \\
(.30)\end{array}$ & $\begin{array}{l}3.35 \\
(.96)\end{array}$ & $\begin{array}{l}1.28 \\
(.65)\end{array}$ & $\begin{array}{l}2.47 \\
(2.60)\end{array}$ & - & - & - & - \\
\hline $\begin{array}{l}\text { CEO tenure } * \\
\text { Income/assets }\end{array}$ & $\begin{array}{l}.00 \\
(.02)\end{array}$ & $\begin{array}{l}.13 \\
(.05)\end{array}$ & $\begin{array}{l}.063 \\
(.045)\end{array}$ & $\begin{array}{l}-.006 \\
(.131)\end{array}$ & - & - & - & - \\
\hline $\begin{array}{l}\text { Log (shareholder } \\
\text { wealth) }\end{array}$ & - & - & - & - & $\begin{array}{l}.24 \\
(.02)\end{array}$ & $\begin{array}{l}.26 \\
(.24)\end{array}$ & $\begin{array}{l}.27 \\
(.05)\end{array}$ & $\begin{array}{c}.53 \\
(.32)\end{array}$ \\
\hline $\begin{array}{l}\text { CEO tenure } * \\
\text { Log (sh. wealth) }\end{array}$ & - & - & - & - & $\begin{array}{l}.003 \\
(.001)\end{array}$ & $\begin{array}{l}.009 \\
(.005)\end{array}$ & $\begin{array}{l}-.005 \\
(.003)\end{array}$ & $\begin{array}{r}-.013 \\
(.010)\end{array}$ \\
\hline CEO tenure & $\begin{array}{c}.01 \\
(.00)\end{array}$ & $\begin{array}{c}-.00 \\
(.01)\end{array}$ & $\begin{array}{l}.010 \\
(.011)\end{array}$ & $\begin{array}{c}.016 \\
(.016)\end{array}$ & $\begin{array}{c}-.002 \\
(.01)\end{array}$ & $\begin{array}{c}-.045 \\
(.04)\end{array}$ & $\begin{array}{c}.044 \\
(.020)\end{array}$ & $\begin{array}{r}.084 \\
(.059)\end{array}$ \\
\hline $\begin{array}{l}\text { Sample size } \\
\text { Adjusted } R^{2}\end{array}$ & $\begin{array}{l}3884 \\
.7030\end{array}$ & 3884 & $\begin{array}{l}740 \\
.757\end{array}$ & 740 & $\begin{array}{r}3841 \\
.715\end{array}$ & 3841 & $\begin{array}{l}743 \\
.700\end{array}$ & 743 \\
\hline
\end{tabular}

a. Dependent variable is the logarithm of total compensation. All nominal variables are expressed in real dollars.

b. In all the luck regressions, both the performance measure and the interaction of the performance measure with the CEO tenure are instrumented. The instruments are the asset-weighted average performance in the two-digit industry and the interactions of the industry performance with the CEO tenure.

c. Sample in columns (1), (2), (5), and (6) is the set of firm-year observations for which there is no large shareholder sitting on the board of directors; sample in columns (3), (4), (7), and (8) is the set of firm-year observations for which there is at least one large shareholder sitting on the board of directors.

d. Each regression includes firm fixed effects, year fixed effects, a quadratic in age, and a quadratic in tenure.

e. Standard errors are in parentheses.

show the greatest pay for luck. Moreover, we would expect this effect to be strongest in those firms where governance is weak and there is no large shareholder present to limit the increased entrenchment. Hence, in the absence of large shareholders, we expect fairly strong governance early in a CEO's tenure, but this governance should weaken over time as he entrenches himself. In the presence of large shareholders, we not only expect stronger governance but also that this stronger governance should last throughout the CEO's tenure. It is harder for a CEO to begin stacking the board when there is a large shareholder around. Thus, we expect a rise in pay for luck with tenure in the absence of a large shareholder, but less of a rise (or even no rise) in the presence of a large shareholder.

Table $\mathrm{V}$ tests this idea. We first sort firms into two groups based on whether they have a large shareholder present on the 
board. ${ }^{28}$ This produces 740 or so data points for firms with large shareholders and 3880 or so data points for firms without large shareholders. For each set, we now separately estimate regression 3 for these two groups with tenure as our governance measure.

Columns (1) and (2) focus on accounting measures of performance in firms without a large shareholder. The second row tells us that while tenure does not affect pay for performance, it greatly increases pay for luck. In fact, a CEO with (roughly) the median tenure of nine years shows about $.13 * 9 / 3.35 \approx 35$ percent greater pay for luck than one who just began at the firm. Let us contrast this with columns (3) and (4) which estimate the same effect for firms with a large shareholder present. Here we find that tenure does not affect pay for luck at all, while, if anything, it seems to raise pay for performance slightly [Gibbons and Murphy 1992]. Thus, pay for luck increases with tenure in the absence of a large shareholder but does not change with tenure in the presence of a large shareholder.

Columns (5) through (8) repeat the tests of columns (1) through (4) for market measures of performance. Here the results are less stark but still very suggestive. Comparing columns (6) and (5), we see that both pay for performance and pay for luck rise with tenure, but pay for luck rises three times as fast (.003 versus .009). The coefficient on the pay for luck, however, is only significant at the 10 percent level. The economic significance, however, stays large as a CEO with a tenure of nine years shows an increase in pay for luck of $.009 * 9 / .26 \approx 31$ percent, but a rise in pay for performance of only 10 percent. In columns (8) and (7) we see that, if anything, pay for luck and pay for performance both diminish with tenure.

While large shareholders correspond most closely to the idea of a principal, other governance measures could also be used. Our data contain two variables that were shown to be important governance measures in the past: the size of the board and the fraction of board members who are insiders in the firm. Small boards are thought to be more effective at governing firms. Yermack [1996], for example, shows that smaller boards correlate with larger $q$ values for firms. Insiders on the board are generally

28. We focus only on large shareholders on the board because these provided the strongest results in Table IV. We have used all large shareholders and found similar, although statistically weaker, results. 
thought to weaken governance. ${ }^{29}$ The first four columns in Table VI estimate the effect of board size on pay for luck. Columns (1) and (2) show that, for accounting measures, the direction of the effect is the opposite of what we postulated but the coefficient is statistically insignificant. Note that the actual size of the coefficient is tiny: even a huge increase in board size of ten board members leads only to a 2 percent drop in pay for luck. Columns (3) and (4), however, show that there are significant effects for market measures of performance and these are of the expected sign. Consider the difference between two boards, one of which has ten board members and one of which has six. The big board firm shows a pay for performance coefficient of .240 and a pay for luck coefficient of .229. The smaller board continues to show a pay for performance coefficient of .228 . But, it shows a pay for luck coefficient of .177. This represents a drop of $(.229-.177) / .177 \approx 30$ percent in the pay for luck coefficient.

The other measure we examine is a measure of insider presence on the board. This variable is measured as fraction of board members who are firm insiders or gray directors. Columns (5) and (6) show that on accounting measures, insider presence dramatically increases the pay for luck coefficient (significant at the 10 percent level). In a board with ten directors, turning one of the outside directors from an outsider to an insider increases pay for luck by $4.51 * .1 / 2.27 \approx 20$ percent. The effect on pay for performance is negative and small. Columns (7) and (8) show that on market performance measures, insider board presence again increases pay for luck, but while the coefficient continues to be economically large, it is statistically quite insignificant.

We turn to our last governance measure in columns (9) through (12), where we construct an index that aggregates all the governance measures used so far: number of large shareholders, number of large shareholders on the board, board size, and insider presence on board. ${ }^{30}$ To form the index, we demean each of

29. Empirical evidence on the effect of insiders on the board can be found in Baysinger and Butler [1985], Weisbach [1988], Rosenstein and Wyatt [1990], Hermalin and Weisbach [1991], Byrd and Hickman [1992], and Brickley, Coles and Terry [1994]. We have also examined CEO ownership and whether the founder is present. We do not report these for space reasons but both produce generally significant effects. Founders and CEOs with high insider ownership both show greater pay for luck.

30. Market valuation of a firm may provide another index of governance. We have examined how a market-to-book measure correlates with the extent of skimming on accounting returns. We found, using a procedure identical to the one used for the governance variables, that firms with higher market-to-book showed lower levels of pay for luck on accounting returns. Clearly it would be conceptually awkward to do a similar exercise for market returns. 
TABLE VI

Corporate Governance and Pay for Luck (LuCK MeAsure Is Mean Industry PERformance) DEPENDENT VARIABLE: $\ln$ (TOTAL COMPENSATION)

\begin{tabular}{lccccccccc}
\hline \hline \multicolumn{1}{c}{$\begin{array}{c}\text { Governance } \\
\text { measure: }\end{array}$} & \multicolumn{9}{c}{ Board size } \\
\multicolumn{1}{c}{ Specification: } & $\begin{array}{c}\text { General } \\
(1)\end{array}$ & $\begin{array}{c}\text { Luck } \\
(2)\end{array}$ & $\begin{array}{c}\text { General } \\
(3)\end{array}$ & $\begin{array}{c}\text { Luck } \\
(4)\end{array}$ & $\begin{array}{c}\text { General } \\
(5)\end{array}$ & $\begin{array}{c}\text { Luck } \\
(6)\end{array}$ & $\begin{array}{c}\text { General } \\
(7)\end{array}$ & $\begin{array}{c}\text { Luck } \\
(8)\end{array}$ \\
\hline Income Assets & 2.61 & 5.19 & - & - & 2.30 & 2.27 & - & - \\
& $(.558)$ & $(1.62)$ & & & $(.453)$ & $(1.24)$ & & \\
Governance* & -.045 & -.093 & - & - & -.482 & 4.51 & - & - \\
Income/assets & $(.043)$ & $(.094)$ & & & $(.853)$ & $(2.69)$ & & \\
Log (shareholder & - & - & .216 & .099 & - & - & .241 & .241 \\
$\quad$ wealth) & & & $(.034)$ & $(.210)$ & & & $(.029)$ & $(.215)$ \\
Governance* & - & - & .002 & .013 & - & - & .027 & .126 \\
Log (sh. wealth) & & & $(.002)$ & $(.006)$ & & & $(.05)$ & $(.190)$ \\
Governance & .012 & .015 & -.013 & -.080 & .158 & -.315 & -.066 & -.742 \\
& $(.005)$ & $(.007)$ & $(.016)$ & $(.041)$ & $(.129)$ & $(.271)$ & $(.407)$ & $(1.29)$ \\
Sample size & 4624 & 4624 & 4584 & 4584 & 4624 & 4624 & 4584 & 4584 \\
Adjusted $R^{2}$ & .695 & & .706 & & .695 & & .706 & \\
\hline
\end{tabular}

Governance measure:

Specification:
General

(9)

2.07

Income Assets

Governance*

Income/assets

Log (shareholder wealth)

\section{Governance*}

Log (sh. wealth)

Governance

Sample size

Adjusted $R^{2}$
Governance index

Luck

(10)

4.23
$(.865)$
-.216
$(.134)$

$\begin{array}{ll}134 & .249\end{array}$

(.016)

$-.003$

(.004)

.010

(.027)

4551

4551

a. Dependent variable is the logarithm of total compensation. All nominal variables are deflated. Each regression includes firm fixed effects, year fixed effects, a quadratic in age, and a quadratic in tenure. Standard errors are in parentheses.

b. "Board size" indicates the number of members of the board of directors, as listed in the proxy statement near the start of the fiscal year. "Fraction insiders" is the fraction of inside and "gray" directors on the board of directors. "Governance index" is the unweighted average of four standardized governance variables (number of large shareholders, number of large shareholders on board, minus board size, and one minus fraction insiders).

c. In all the luck regressions, both the performance measure and the interaction of the performance measure with the governance measure are instrumented. The instruments are the asset-weighted average performance in the two-digit industry and the interactions of the industry performance with that governance measure.

the four governance variables, divide it by its standard deviation, and then take the sum of these standardized variables. For board size, we use negative of board size in this procedure. For fraction 
of insiders on the board, we use one minus that fraction. This guarantees that the resulting governance index has larger values whenever the firm is better governed. ${ }^{31}$

For accounting measures of performance (columns (9) and (10)), we again find that pay for luck diminishes with the governance, while pay for performance does not change. The coefficient, however, is only significant at the 10 percent level. To gauge the magnitude of these effects, consider a one-standarddeviation increase in the governance index, about 2 . Such an increase leads to $\mathrm{a}-.216 * 2 / 4.23 \approx 10$ percent fall in the pay for luck coefficient. When we use market measures (columns (11) and (12)), increases in the governance index greatly reduce pay for luck but hardly affect pay for performance. In this case, the coefficients are significant at the 5 percent level. Moreover, their magnitude is bigger. A one-standard-deviation increase in governance decreases pay for luck by 26 percent.

Finally, we investigate the robustness of our findings. The primary concern one might have is that we have not adequately controlled for firm size. One might worry that large firms have quite different pay for performance sensitivities than small firms [Baker and Hall 1999]. If this also translates into different pay for luck sensitivities, the estimates above might confuse this size effect for a governance "effect."

In Table VII we address this problem by controlling for size interacted with performance. We reestimate equation (3) but this time include a term Size $*$ perf $_{i t}$. Our measure of size in these regressions is average log real assets of the firm over the period. We report the results for two governance measures, large shareholders on the board and the governance index, although we have reestimated all the previous tables with these controls and found similar results. Columns (1) through (4) are to be compared with columns (5) through (8) of Table IV. We see that the effect of governance on the filtering of accounting rates of return in fact strengthens when these controls are added $(-2.23$ versus -1.48$)$.

31. This particular way of proceeding will tend to count large shareholders on the board twice, once as on the board and once as general large shareholders. This is a crude way of incorporating our prior belief (supported by the findings in Table IV) that large shareholders on the board matter more. When we use either measure in the index alone, we find qualitatively similar results. We have also estimated a regression in which we include all four governance measures (and their interactions) together. These regressions showed all the governance measures entering with the same sign and only the large shareholder variables being statistically significant. 
TABLE VII

Corporate Governance and Pay for Luck Robustness Checks

(Luck Measure Is Mean Industry Performance)

DEPENDENT VARIABLE: In (TOTAL COMPENSATION)

\begin{tabular}{|c|c|c|c|c|c|c|c|c|}
\hline \multirow{2}{*}{$\begin{array}{l}\text { Governance } \\
\text { measure: } \\
\text { Specification: }\end{array}$} & \multicolumn{4}{|c|}{ Large shareholders on board } & \multicolumn{4}{|c|}{ Governance index } \\
\hline & $\begin{array}{c}\text { General } \\
\text { (1) }\end{array}$ & $\begin{array}{c}\text { Luck } \\
(2)\end{array}$ & $\begin{array}{c}\text { General } \\
\text { (3) }\end{array}$ & $\begin{array}{c}\text { Luck } \\
(4)\end{array}$ & $\begin{array}{c}\text { General } \\
\text { (5) }\end{array}$ & $\begin{array}{c}\text { Luck } \\
(6)\end{array}$ & $\begin{array}{c}\text { General } \\
\text { (7) }\end{array}$ & $\begin{array}{l}\text { Luck } \\
(8)\end{array}$ \\
\hline Income Assets & $\begin{array}{r}.288 \\
(1.14)\end{array}$ & $\begin{array}{c}36.9 \\
(14.6)\end{array}$ & - & - & $\begin{array}{l}-.570 \\
(1.31)\end{array}$ & $\begin{array}{l}12.3 \\
(6.17)\end{array}$ & - & - \\
\hline $\begin{array}{l}\text { Governance* } \\
\text { Income/assets }\end{array}$ & $\begin{array}{c}-.118 \\
(.18)\end{array}$ & $\begin{array}{r}-2.23 \\
(.52)\end{array}$ & - & - & $\begin{array}{l}.056 \\
(.061)\end{array}$ & $\begin{array}{c}-.197 \\
(.126)\end{array}$ & - & - \\
\hline $\begin{array}{l}\text { Log (shareholder } \\
\text { wealth) }\end{array}$ & - & - & $\begin{array}{c}.223 \\
(.086)\end{array}$ & $\begin{array}{c}-.136 \\
(.334)\end{array}$ & - & - & $\begin{array}{c}.251 \\
(.098)\end{array}$ & $\begin{array}{r}-.194 \\
(.345)\end{array}$ \\
\hline $\begin{array}{l}\text { Governance* } \\
\text { Log (shareholder } \\
\text { wealth) }\end{array}$ & - & - & $\begin{array}{c}-.018 \\
(.016)\end{array}$ & $\begin{array}{c}-.059 \\
(.053)\end{array}$ & - & - & $\begin{array}{c}-.003 \\
(.004)\end{array}$ & $\begin{array}{r}-.027 \\
(.012)\end{array}$ \\
\hline Governance & $\begin{array}{l}-.010 \\
(.021)\end{array}$ & $\begin{array}{l}.127 \\
(.038)\end{array}$ & $\begin{array}{l}.094 \\
(.109)\end{array}$ & $\begin{array}{l}.365 \\
(.357)\end{array}$ & $\begin{array}{c}-.019 \\
(.007)\end{array}$ & $\begin{array}{c}-.002 \\
(.010)\end{array}$ & $\begin{array}{l}.007 \\
(.029)\end{array}$ & $\begin{array}{l}.170 \\
(.085)\end{array}$ \\
\hline $\begin{array}{l}\text { Firm Size * } \\
\quad \text { Performance? }\end{array}$ & Yes & Yes & Yes & Yes & Yes & Yes & Yes & Yes \\
\hline Sample size & 4621 & 4621 & 4581 & 4581 & 4610 & 4610 & 4551 & 4551 \\
\hline Adjusted $R^{2}$ & .695 & - & .706 & - & .695 & - & .705 & - \\
\hline
\end{tabular}

a. Dependent variable is the logarithm of total compensation. Performance measure is operating income to total assets. All nominal variables are expressed in real dollars. Each regression includes firm fixed effects, year fixed effects, a quadratic in age, and a quadratic in tenure.

b. In all the luck regressions, both the performance measure and the interaction of the performance measure with the governance measure are instrumented. The instruments are the asset-weighted average performance in the two-digit industry and the interactions of the industry performance with that governance measure.

c. "Large shareholders on board" indicates the number of blocks of at least 5 percent of the firm's common shares that are held by directors of the board. "Governance index" is the unweighted average of four standardized governance variables (number of large shareholders, number of large shareholders on board, minus board size, and one minus fraction insiders). "Firm size" indicates average log assets over the same period.

d. Standard errors are in parentheses.

The effects on market performance measures, however, weaken slightly (.059 versus .076). Columns (5) through (8) use the governance index and are to be compared with columns (9) through (12) in Table VI. This comparison shows that the results weaken very slightly (-.197 versus -.216) for accounting measures as well as for market measures (-.027 versus -.033). For both governance measures, however, the results remain economically significant. In two of the cases (column (4) and to some extent column (6)), they remain statistically insignificant. In the other two, they remain statistically significant.

We have also attempted other robustness checks. We checked whether filtering may happen over longer time horizons by aggregating our data over several years as well as looking at lags. We also allowed for interactions between performance and year in 
our regressions since there are known to be changes in the pay for performance sensitivity over this time period. These modifications did not alter our qualitative findings.

\section{CONCLUSION}

CEOs are rewarded for luck. Moreover, pay for luck is as large as pay for general pay for performance. Pay for luck also appears on the most discretionary components of compensation, salary and bonus. Looking closer, we found that pay for luck is strongest among poorly governed firms. Adding a large shareholder on the board, for example, decreased the pay for luck by 23 to 33 percent. This finding weakens two prominent explanations of pay for luck: "Paying for luck is optimal" and "Filtering out luck is impossible."

More broadly, these results encourage a revision of our views on CEO pay. Poorly governed firms fit the predictions of the skimming view. Well-governed firms fit the predictions of the contracting view better. They are to remove some luck in setting pay. This suggests that both views hold some sway. Other empirical facts support this idea. In Bertrand and Mullainathan [2000b] we showed that well-governed firms charged CEOs more for the options they were granted. Options contain a gift component because even if the CEO does nothing they have value from the intrinsic volatility of the stock (their Black-Scholes value). We show that firms with large shareholders, smaller boards, and so on, are better able to charge their CEOs and better able to remove this gift component by reducing the other components of pay. In other words, principal agent models work best when there are in fact individuals around to act as principals.

Several unanswered questions remain. First, it is unclear what effects the reward for luck has on overall CEO utility. Does competition in the market for CEOs force the mean level of pay at initial hire to adjust so that there are no ex ante rents to be had? Or is the hiring process sufficiently closed or captured by insiders that such adjustments are small? Second, while formal models of the contracting view abound, there is no careful analysis of the skimming model. Without such an analysis, our understanding of skimming will necessarily remain vague. What are the exact mechanisms by which skimming is constrained? How specifically does better governance translate into better pay packages? The results in this paper suggest that more energy should be devoted to clarifying the skimming alternative. 
ApPEndix 1: SUmmary Statistics-50 LaRgest U. S. OIL Companies CEOS

\begin{tabular}{lcc}
\hline & Mean & S. D. \\
\hline Age of CEO & 58.562 & 7.892 \\
Tenure of CEO & 10.181 & 9.781 \\
Total compensation & 608.269 & 597.194 \\
ln (Total Compensation) & 6.125 & .722 \\
\hline \hline
\end{tabular}

a. Data set is 50 of the 51 largest U. S. oil companies over the period 1977-1994.

b. Total Compensation is defined as the sum of salary and bonus (cash and stock bonus), company contributions to thrift plans, other annual income, and the value of the options granted to the CEO during that year, in thousands of 1977 dollars.

Appendix 2: PAy for Luck: First-StTage Regressions (LuCK Measure Is Exchange Rate Shocks) ${ }^{\mathrm{A}}$

\begin{tabular}{lccc}
\hline \multicolumn{1}{c}{ Dep. Var.: } & Income & Inc. to Assets & Ln (Sh. Wealth) \\
& $(1)$ & $(2)$ & $(3)$ \\
$2 \%<$ Appr. $<4 \%$ & -56.588 & -.006 & -.039 \\
(Current) & $(26.408)$ & $(.004)$ & $(.047)$ \\
$2 \%<$ Appr. $<4 \%$ & -15.428 & .004 & -.027 \\
(Lagged) & $(24.271)$ & $(.004)$ & $(.048)$ \\
Appr. $>4 \%$ & -68.903 & -.013 & -.034 \\
(Current) & $(32.039)$ & $(.005)$ & $(.058)$ \\
Appr. $>4 \%$ & -12.045 & .006 & .053 \\
(Lagged) & $(30.646)$ & $(.005)$ & $.055)$ \\
$2 \%<$ Depr. $<4 \%$ & 76.642 & -.000 & .153 \\
(Current) & $(24.647)$ & $(.004)$ & $. .045)$ \\
$2 \%<$ Depr. $<4 \%$ & 85.858 & .010 & .114 \\
(Lagged) & $(25.942)$ & $(.004)$ & $.094)$ \\
Depr. $>4 \%$ & 45.482 & .007 & $(.050)$ \\
(Current) & $(27.761)$ & $(.005)$ & .046 \\
Depr. $>4 \%$ & 76.345 & .017 & $(.054)$ \\
(Lagged) & $(29.791)$ & $(.005)$ &. .077 \\
Exch. rate index growth & -19.273 & -.000 & $(.302)$ \\
(Current) & $(167.134)$ & $(.030)$ & .237 \\
Exch. rate index growth & 216.140 & .038 & $(.316)$ \\
(Lagged) & $(175.302)$ & $(.031)$ & 1713 \\
Sample size & 1737 & 1729 & .873 \\
Adjusted $R^{2}$ & .622 & .700 & 2.47 \\
F-stat & 3.48 & 2.6 & $(.006)$ \\
(prob $>F-$ stat $)$ & $(.000)$ & $(.004)$ & \\
= & & & \\
\hline
\end{tabular}

a. Dependent variable is the level of income in column (1), the ratio of operating income to total assets in column (2) and the log value of shareholder wealth in column (3). Income and shareholder wealth are expressed in millions of 1977 dollars. $2 \%<$ Appr. $<4 \%$ is dummy variable that equals 1 if the industryspecific exchange rate index appreciated by more than $2 \%$ and less than $4 \%$ since the previous year. All the other appreciation and depreciation dummies are defined in a similar way.

b. Each regression includes firm fixed effects and year fixed effects. All regressions also include a quadratic in CEO age and a quadratic in CEO tenure.

c. The 3 regressions are the first-stage regressions associated with columns (2), (4), and (8) in Panel A of Table 3.

d. Standard errors are in parentheses. 
Princeton University, National Bureau of Economic Research, and Center FOR ECONOMIC POLICY RESEARCH

Massachusetts Institute of Technology and National Bureau of Economic RESEARCH

\section{REFERENCES}

Abowd, John M., and David S. Kaplan, "Executive Compensation; Six Questions That Need Answering," Journal of Economic Perspectives, XIII (1999), 145-168.

Aggarwal, Rajesh K., and Andrew A. Samwick, "The Other Side of the Trade-Off: The Impact of Risk on Executive Compensation," Journal of Political Economy, CVII (1999a), 65-105.

Aggarwal, Rajesh K., and Andrew A. Samwick, "Executive Compensation, Strategic Competition, and Relative Performance Evaluation: Theory and Evidence," Journal of Finance, LIV (1999b), 1999-2043.

Baker, George, Robert Gibbons, and Kevin J. Murphy, "Subjective Performance Measures in Optimal Incentive Contracts," Quarterly Journal of Economics, CIX (1994), 1125-1156.

Baker, George, and Brian Hall, "Understanding Top Management Incentives: Firm Size, Risk and CEO Effort," Harvard Business School, 1998.

Baysinger, Robert D., and Henry N. Butler, "Corporate Governance and the Board of Directors: Performance Effects of Changes in Board Composition," Journal of Law, Economics and Organization, I (1985), 101-124.

Bertrand, Marianne, "From the Invisible Handshake to the Invisible Hand? How Import Competition Changes the Employment Relationship," National Bureau of Economic Research Working Paper No. 6900, 1999.

Bertrand, Marianne, and Sendhil Mullainathan, "Corporate Governance and Executive Compensation: Evidence from Takeover Legislation," Princeton University, 1999.

Bertrand, Marianne, and Sendhil Mullainathan, "Agents with and without Principals," American Economic Review, XC (2000a), 203-208.

Bertrand, Marianne, and Sendhil Mullainathan, "Do CEOs Set Their Own Pay? The Ones without Principals Do," National Bureau of Economic Research Working Paper No. 7604, 2000b.

Blanchard, Olivier J., Florencio Lopez-de-Silanes, and Andrei Shleifer, "What Do Firms Do with Cash Windfalls?" Journal of Financial Economics, XXXVI (1994), 337-360.

Brickley, James A., Jeffrey L. Coles, and Rory L. Terry, "Outside Directors and the Adoption of Poison Pills," Journal of Financial Economics, XXXV (1994), 371-390.

Byrd, John W., and Kent A. Hickman, "Do Outside Directors Monitor Managers?" Journal of Financial Economics, XXXII (1992), 195-221.

Crystal, Graef, In Search of Excess: The Overcompensation of American Executives (New York, NY: W.W. Norton Co., 1991).

$\rightarrow$ Denis, David, and Jan Serrano, "Active Investors and Management Turnover Following Unsuccessful Control Contests," Journal of Financial Economics, XL (1996), 239-266.

Diamond, Peter, "Managerial Incentives: On the Near Linearity of Optimal Compensation," Journal of Political Economy, CVI (1998), 931-957.

Durell, Alan, "Attribution in Performance Evaluation," Dartmouth College, 1999.

Garen, John E., "Executive Compensation and Principal-Agent Theory," Journal of Political Economy, CII (1994), 1175-1199.

Gibbons, Robert, and Kevin J. Murphy, "Relative Performance Evaluation for Chief Executive Officers," Industrial and Labor Relations Review, XLIII (1990), S30-S51.

Gibbons, Robert, and Kevin J. Murphy, "Optimal Incentives in the Presence of Career Concerns: Theory and Evidence," Journal of Political Economy, C (1992), 468-505.

Haid, Michael, Incentive Compensation and the Market for Corporate Control: Substitutive Forces to Discipline Management of Publicly Held Organizations in the U. S.: Empirical Evidence From the Oil Industry 1977-1994 (Bern, Switzerland: Haupt, 1997). 
Hall, Brian J., "The Design of Multi-Year Stock Option Plans," Journal of Applied Corporate Finance, XII (1999), 97-106.

Hall, Brian J., and Jeffrey B. Liebman, “Are CEOs Really Paid Like Bureaucrats?" Quarterly Journal of Economics, CXIII (1998), 653-691.

$\rightarrow$ Hermalin, Benjamin, and Michael Weisbach, "The Effects of Board Composition and Direct Incentives on Firm Performance," Financial Management, XX (1991), 101-112.

Himmelberg, Charles, and R. Glenn Hubbard, "Incentive Pay and the Market for CEOs: An Analysis of Pay-For-Performance Sensitivity," Columbia University, 2000.

$\rightarrow$ Holmstrom, Bengt, "Moral Hazard and Observability," Bell Journal of Economics, $\mathrm{X}(1979), 74-91$.

Holmstrom, Bengt, and Paul Milgrom, "Aggregation and Linearity in the Provision of Intertemporal Incentives," Econometrica, LV (1987), 303-328.

Hubbard, R. Glenn, and Darius Palia, "Executive Pay and Performance: Evidence from the U. S. Banking Industry," Journal of Financial Economics, XXXIX (1994), 105-130.

Janakiraman, Surya N., Richard A. Lambert, and David F. Larcker, "An Empirical Investigation of the Relative Performance Evaluation Hypothesis," Journal of Accounting Research, XXX (1992), 53-69.

Jensen, Michael, and Kevin J. Murphy, "Performance Pay and Top-Management Incentives," Journal of Political Economy, XCVIII (1990), 225-264.

Joskow, Paul L., Nancy L. Rose, and Catherine D. Wolfram, "Political Constraints on Executive Compensation: Evidence from the Electric Utility Industry," Rand Journal of Economics, XXVII (1996), 165-182.

- "Corporate Performance and Managerial Remuneration: An Empirical Investigation of Managerial Labor Contracts," Rand Journal of Economics, XVII (1986), 59-76.

_- "Executive Compensation," Handbook of Labor Economics, O. Ashenfelter and D. Card, eds. (Amsterdam, The Netherlands: North-Holland, 1999).

Revenga, Ana L., "Exporting Jobs? The Impact of Import Competition on Employment and Wages in U. S. Manufacturing," Quarterly Journal of Economics, CVII (1992), 255-284.

Rosenstein, Stuart, and Jeffrey G. Wyatt, "Outside Directors, Board Independence, and Shareholder Wealth," Journal of Financial Economics, XXVI (1990), 175-191.

Shea, John, "Nominal Illusion: Evidence from Major League Baseball," University of Maryland, 1999.

$\rightarrow$ Shivdasani, Anil, "Board Composition, Ownership Structure, and Hostile Takeovers," Journal of Accounting and Economics, XVI (1993), 167-198.

Shleifer, Andrei, and Robert Vishny, "Large Shareholders and Corporate Control," Journal of Political Economy, XCIV (1986), 461-488.

Tufano, Peter, "Who Manages Risk? An Empirical Examination of Risk Management Practices in the Gold Mining Industry," Journal of Finance, LI (1996), 1097-1137.

Weisbach, Michael, "Outside Directors and CEO Turnover," Journal of Financial Economics, XX (1988), 431-460.

Yermack, David, "Do Corporations Award Stock Options Effectively?" Journal of Financial Economics, XXXIX (1995), 237-269.

$-\rightarrow-$, "Higher Market Valuation of Companies with a Small Board of Directors," Journal of Financial Economics, XL (1996), 185-211.

Zeckhauser, Richard J., and John Pound, "Are Large Shareholders Effective Monitors? An Investigation of Share Ownership and Corporate Performance," Asymmetric Information, Corporate Finance and Investment, R. Glenn Hubbard, ed. (Chicago, IL: University of Chicago Press, 1990). 